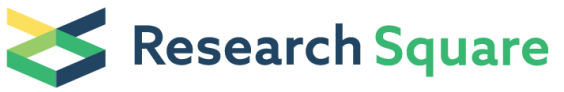 \\ Preprints are preliminary reports that have not undergone peer review. \\ They should not be considered conclusive, used to inform clinical practice, \\ or referenced by the media as validated information.
}

\section{Idiopathic Pulmonary Fibrosis and Diabetes Mellitus: A Meta-Analysis and Systematic Review}

\section{Le Bai}

Affiliated Hospital of Nanjing University of Chinese Medicine: Jiangsu Province Academy of Traditional Chinese Medicine

\section{Li Zhang}

Affiliated Hospital of Nanjing University of Chinese Medicine: Jiangsu Province Academy of Traditional Chinese Medicine

\section{Tingyu Pan}

Affiliated Hospital of Nanjing University of Chinese Medicine: Jiangsu Province Academy of Traditional Chinese Medicine

Wei Wang

Affiliated Hospital of Nanjing University of Chinese Medicine: Jiangsu Province Academy of Traditional Chinese Medicine

\section{Dian Wang}

Affiliated Hospital of Nanjing University of Chinese Medicine: Jiangsu Province Academy of Traditional Chinese Medicine

\section{Cassidy Turner}

Arizona State University

Xianmei Zhou ( $\square$ zhouxianmeijs@aliyun.com )

Affiliated Hospital of Nanjing University of Chinese Medicine: Jiangsu Province Academy of Traditional Chinese Medicine

\section{Hailang $\mathrm{He}$}

Affiliated Hospital of Nanjing University of Chinese Medicine: Jiangsu Province Academy of Traditional Chinese Medicine

\section{Research Article}

Keywords: Idiopathic pulmonary fibrosis, diabetes mellitus, meta-analysis, systematic review

Posted Date: March 3rd, 2021

DOI: https://doi.org/10.21203/rs.3.rs-269500/v1

License: (c) (i) This work is licensed under a Creative Commons Attribution 4.0 International License. Read Full License 


\section{Abstract}

Background: Idiopathic pulmonary fibrosis (IPF) is a chronic diffuse interstitial lung disease, of which the etiology has been poorly understood. Several studies have focused on the relationship between IPF and diabetes mellitus (DM) in the past years but have failed to reach a consensus. This meta-analysis aimed to examine the association between diabetes to IPF.

Methods: We accumulated studies investigating the association between DM and IPF from databases including Medline, Cochrane Library, Embase, Web of Science, and China National Knowledge Infrastructure. RevMan 5.3 and the Newcastle-Ottawa Scale (NOS) were utilized to analyze the data and assess the quality of the included studies. The value of odds ratio (OR) with 95\% confidence interval (Cl) was used as the measure to estimate the risk of DM in IPF. Heterogeneity was assessed by $R$ statistics. We also performed subgroup analysis, meta-regression, and Egger's test for bias analysis.

Results: Nine case-control studies with 5,096 IPF patients and 19,095 control subjects were included in the present meta-analysis, which indicated that DM could increase the risk of IPF (OR: 1.65, 95\% Cl: 1.30-2.10; $P<0.0001)$. Metaregression and subgroup analysis negated the influence of covariates like cigarette smoking, age and gender, but the heterogeneity existed and could not be fully explained.

Conclusion: The meta-analysis indicated that DM is highly probably related to IPF. Further rigorously designed studies are required to confirm the present findings and investigate the possible mechanisms behind the effect of DM on IPF.

\section{Introduction}

Idiopathic pulmonary fibrosis (IPF) is a progressive and fatal pulmonary disease with an annual cumulative prevalence of 18.2 cases per 100,000 persons in America[1] while a median survival of only $3-5$ years[2, 3]. IPF is characterized pathologically by proliferation and differentiation of lung fibroblasts. In the past decade, the understanding of IPF pathogenesis has shifted from an inflammatory-driven process[4] to aberrant activation of the alveolar epithelial cells hypothesis[5], which may be connected with cigarette smoking, genetic factors, chronic viral infections, etc, based on collaborative guidelines[6]. Nevertheless, the exact etiology of IPF remains unclear.

In recent years, it has been observed that IPF patients are often additionally diagnosed with diabetes mellitus (DM), resulting in increased research interest in the correlation between these two diseases. Firstly, two earlier case-controls studies $[7,8]$ were successively conducted in Japan but obtained opposite conclusions. Subsequent clinical observational researches $[9,10]$ suggested that DM increased the risk of IPF, which inspired experiments related to antidiabetic treatment for IPF. Interestingly, using mice animal models, it was revealed that metformin could reverse established lung fibrosis[11-15], however, a post hoc analysis[16], which investigated the effect of combinations therapy in IPF (pirfenidone/pirfenidone + metformin), concluded that metformin had no effect on clinically relevant outcomes. Furthermore, another pooled analysis demonstrated that metformin might increase the risk of disease progression when in combination with proton pump inhibitors, angiotensin II receptor blockers or thyroid medications[17].

Due to the conflicting results in the existing studies, it remains controversial whether DM is truly correlated with IPF and to date, the evidence for the relevance between DM and IPF has not been systematically evaluated. Hence, in the present study, we conducted a meta-analysis and systematic review, aiming to assess the association between DM and the incidence of IPF. 


\section{Materials And Methods}

We performed meta-analysis and wrote this report referring to the Meta-analysis Of Observational Studies in Epidemiology (MOOSE) proposal[18] and the Preferred Reporting Items for Systematic Reviews and Meta-Analyses (PRISMA) statement[19].

\section{Literature Search}

We searched databases including Medline, Cochrane Library, Embase, Web of Science and China National Knowledge Infrastructure. The following items were searched in databases as keywords or random words: "pulmonary fibrosis", "diabetes", "risk factors" and such searches were additionally filtered for articles published in any language leading up to September 30, 2020 (Complete search strategy presented in Appendix 1)

\section{Inclusion criteria and exclusion criteria}

Case-control studies or cohort studies were selected. The case groups were all diagnosed with IPF in accordance with clinical history, High-Resolution Computed Tomography (HRCT), and when available, lung biopsy. Also, a calculated measure of association between DM and IPF was required. Studies focusing on progression or prognosis of IPF and studies lacking general information about control groups were excluded.

\section{Data Extraction}

Two researchers (L.B. and L.Z.) managed data extraction independently, reviewing the title, abstract, and full text of each article, and discussed or consulted a third researcher (T.P.) when disputations arose. The following are included:

(1) basic information of each study including author, publication year, study design, etc; (2) characteristics of case and control groups; (3) diagnostic methods of MD and IPF; (4) the number of diabetics in case and control groups; and (5) potential sources of biases.

\section{Quality Assessment}

The Newcastle-Ottawa Scale (NOS) was used for quality assessment of included studies, covering three domains: selection of groups, comparability of groups and ascertainment of exposure[20]. The NOS score ranges from 0 to 9 stars and studies that receive 5 stars or more are regarded as high quality. We evaluated the diagnostic criteria of IPF and DM in each study for the possibility of selection bias. Cigarette smoking, age, gender, environmental exposure and genetic factors, which may induce IPF and bring about information bias, were deemed as covariates and all taken into consideration when estimating whether control subjects were adequately selected.

\section{Statistical Analysis}

In our meta-analysis, odds ratio with $95 \%$ confidence interval $(95 \% \mathrm{Cl})$ was used as the effect measure. Heterogeneity was assessed by $R$ statistics and random effect model was chosen when heterogeneity was significant $(R>50 \%)$, otherwise, fixed effect model was selected. Forest plots were used to display the results from individual studies and pooled estimates, and $P<0.05$ were regarded as statistically significant. Trial Sequential Analysis (TSA) was used for estimate of evidence size and reliability of the conclusion[21,22]. We also performed sensitivity and subgroup analyses to assess resources of heterogeneity. Meta-regression and Egger's test[23] were utilized for bias analysis. Data analysis was performed using RevMan 5.3, Stata 12, and TSA 0.9 beta.

\section{Results}




\section{Study Selection and Characteristics}

As is briefly illustrated in Fig. 1, out of the 1528 articles reviewed, 9 studies[7-10, 24-28] from 5 countries finally met our eligibility. All studies were case-control and distinguished as high-quality by NOS assessment. General population was selected as control groups in six studies[7, 8, 10, 25-27], one study included only healthy volunteers[24], and the remaining two[9, 28] included patients with other chronic pulmonary diseases. IPF was diagnosed based on clinical history, HRCT, and lung biopsy while diagnosis of DM could be established with any objective method such as fasting blood glucose or simple by clinical symptoms combined with clinical history. More details are displayed in Table 1. 
Table 1

Characteristics of Included Studies

\begin{tabular}{|c|c|c|c|c|c|c|c|}
\hline Study & Country & Design & NOS & IG & CG & $\begin{array}{l}\text { Method of IPF } \\
\text { Diagnosis }\end{array}$ & $\begin{array}{l}\text { Method of } \\
\text { DM } \\
\text { Diagnosis }\end{array}$ \\
\hline $\begin{array}{l}\text { Enomoto et } \\
\text { al[7] } 2003\end{array}$ & Japan & $\begin{array}{l}\text { Case- } \\
\text { Control }\end{array}$ & 8 & 52 & $\begin{array}{l}184 \text { people matched } \\
\text { for age and sex with } \\
\text { no lung disease by } \\
\text { chest radiographs }\end{array}$ & ATS/ERS criteria[65] & $\begin{array}{l}\text { FBG > } \\
6 \mathrm{mmol} / \mathrm{L} \\
\text { and/or } \\
\text { HbAlc }>6 \% \\
\text { in } \\
\text { combination } \\
\text { with any } \\
\text { treatment } \\
\text { history }\end{array}$ \\
\hline $\begin{array}{l}\text { Miyake et } \\
\text { al[8] } 2005\end{array}$ & Japan & $\begin{array}{l}\text { Case- } \\
\text { Control }\end{array}$ & 8 & 104 & $\begin{array}{l}56 \text { acute bacterial } \\
\text { pneumonia, and } 4 \\
\text { common cold, } \\
\text { matched by age and } \\
\text { sex }\end{array}$ & ATS/ERS criteria[65] & $\begin{array}{l}\text { Medication } \\
\text { or diet } \\
\text { treatment } \\
\text { history }\end{array}$ \\
\hline $\begin{array}{l}\text { Gribbin et } \\
\text { al[10] } 2009\end{array}$ & $\begin{array}{l}\text { United } \\
\text { Kingdom }\end{array}$ & $\begin{array}{l}\text { Case- } \\
\text { Control }\end{array}$ & 6 & 920 & $\begin{array}{l}3593 \text { control } \\
\text { subjects matched by } \\
\text { age, gender and } \\
\text { general practice }\end{array}$ & $\begin{array}{l}\text { Read Code } \\
\text { (diagnostic terms) in } \\
\text { THIN database }\end{array}$ & Read Code \\
\hline $\begin{array}{l}\text { Ma.C et } \\
\text { al[9] } 2010\end{array}$ & Mexico & $\begin{array}{l}\text { Case- } \\
\text { Control }\end{array}$ & 6 & 97 & $\begin{array}{l}560 \text { patients, } 461 \\
\text { with other } \\
\text { pulmonary diseases } \\
\text { and } 98 \text { with } \\
\text { otorhinolaryngologic } \\
\text { problems }\end{array}$ & ATS/ERS criteria[65] & $\begin{array}{l}\text { FPG > } \\
6 \mathrm{mmol} / \mathrm{L} . \\
\text { Clinical } \\
\text { history and } \\
\text { medication } \\
\text { therapy } \\
\text { were also } \\
\text { referred to }\end{array}$ \\
\hline $\begin{array}{l}\text { Garcia- } \\
\text { Sancho et } \\
\text { al[24] } 2011\end{array}$ & Mexico & $\begin{array}{l}\text { Case- } \\
\text { Control }\end{array}$ & 8 & 100 & $\begin{array}{l}263 \text { healthy control } \\
\text { subjects matched } \\
\text { for age, sex, and } \\
\text { place of residence }\end{array}$ & ATS/ERS criteria[65] & $\begin{array}{l}\text { Clinical } \\
\text { symptoms } \\
\text { and } \\
\text { medication } \\
\text { history }\end{array}$ \\
\hline $\begin{array}{l}\text { Kim et } \\
\text { al[25] } 2015\end{array}$ & Korea & $\begin{array}{l}\text { Case- } \\
\text { Control }\end{array}$ & 7 & 460 & $\begin{array}{l}1925 \text { control } \\
\text { subjects matched } \\
\text { with age, gender, } \\
\text { and smoking habits }\end{array}$ & $\begin{array}{l}\text { ATS/ERS/JRS/ALAT } \\
\text { criteria[64] }\end{array}$ & $\begin{array}{l}\text { FPG > } \\
6 \mathrm{mmol} / \mathrm{L} \\
\text { together } \\
\text { with clinical } \\
\text { history }\end{array}$ \\
\hline $\begin{array}{l}\text { Dalleywater } \\
\text { et al[27] } \\
2015\end{array}$ & Kingdom & Control & 8 & 3211 & $\begin{array}{l}12307 \text { control } \\
\text { subjects, matched } \\
\text { for age, sex, and } \\
\text { general practice }\end{array}$ & $\begin{array}{l}\text { A new diagnosis } \\
\text { prior to previous } \\
\text { Read Code }\end{array}$ & Read Code \\
\hline
\end{tabular}

NOS: Newcastle-Ottawa Scale. IPF: Idiopathic Pulmonary Fibrosis. DM: Diabetes Mellitus. IG: IPF Group. CG: Control Group. THIN: The Health Improvement Network. FBG: Fasting Blood Glucose. FPG: Fasting Plasma Glucose. ATS: American Thoracic Society. ERS: European Respiratory Society. JRS: Japanese Respiratory Society. ALAT: Latin American Thoracic Association. 


\begin{tabular}{|c|c|c|c|c|c|c|c|}
\hline Study & Country & Design & NOS & IG & CG & $\begin{array}{l}\text { Method of IPF } \\
\text { Diagnosis }\end{array}$ & $\begin{array}{l}\text { Method of } \\
\text { DM } \\
\text { Diagnosis }\end{array}$ \\
\hline $\begin{array}{l}\text { Zhong et } \\
\text { al[28] } 2016\end{array}$ & China & $\begin{array}{l}\text { Case- } \\
\text { Control }\end{array}$ & 6 & 108 & $\begin{array}{l}115 \text { patients without } \\
\text { respiratory failure or } \\
\text { other underlying } \\
\text { disorders }\end{array}$ & $\begin{array}{l}\text { Guidance for } \\
\text { Diagnostic and } \\
\text { Treatment of } \\
\text { Pulmonary Fibrosis } \\
\text { (Chinese Thoracic } \\
\text { Society 2002) }\end{array}$ & $\begin{array}{l}\text { FPG > } \\
6 \mathrm{mmol} / \mathrm{L} \\
\text { and/or 2- } \\
\text { hour PG > } \\
11.1 \mathrm{mmol} / \mathrm{L}\end{array}$ \\
\hline $\begin{array}{l}\text { Xu et al[26] } \\
2020\end{array}$ & China & $\begin{array}{l}\text { Case- } \\
\text { Control }\end{array}$ & 7 & 44 & $\begin{array}{l}88 \text { patients without } \\
\text { evidence of lung } \\
\text { disease on } \\
\text { computed } \\
\text { tomography, } \\
\text { matched for age } \\
\text { and sex }\end{array}$ & ATS/ERS criteria[6] & $\begin{array}{l}\text { FPG > } \\
7 \mathrm{mmol} / \mathrm{L} \text {. } \\
\text { Clinical } \\
\text { history was } \\
\text { also used } \\
\text { for } \\
\text { diagnosis }\end{array}$ \\
\hline \multicolumn{8}{|c|}{$\begin{array}{l}\text { NOS: Newcastle-Ottawa Scale. IPF: Idiopathic Pulmonary Fibrosis. DM: Diabetes Mellitus. IG: IPF Group. CG: Contro } \\
\text { Group. THIN: The Health Improvement Network. FBG: Fasting Blood Glucose. FPG: Fasting Plasma Glucose. ATS: } \\
\text { American Thoracic Society. ERS: European Respiratory Society. JRS: Japanese Respiratory Society. ALAT: Latin } \\
\text { American Thoracic Association. }\end{array}$} \\
\hline
\end{tabular}

\section{Meta-Analysis}

A total of 5,096 IPF cases and 19,095 control subjects were involved in the analysis (Fig. 2), suggesting that DM and IPF should be related (OR: 1.65, 95\% Cl: 1.30-2.10; $P<0.0001$ ), based on statistical reliability verified by the subsequent trial sequential analysis (Fig. 3). The heterogeneity was significant $\left({ }^{2}=68 \%\right)$ with no obvious sources of biases found among the sensitivity analyses (Fig. 4). Therefore, we performed subgroup analyses to investigate factors that possibly contribute (Table 2). The result remained consistent in separate analyses regardless of community or hospital controls, and irrespective of diagnostic criteria of IPF/DM or characteristics of control groups (healthy subjects, general population or patients with pulmonary disorders). When smoking status, age, and gender were accounted for in case and control groups, the heterogeneity still existed as before. 
Table 2

Subgroup Analysis

\begin{tabular}{|c|c|c|c|c|c|c|c|c|c|}
\hline \multirow{2}{*}{$\begin{array}{l}\text { Study Characteristic } \\
\text { Groups matched by age } \\
\text { and sex[7, 8, 10, 24-27] }\end{array}$} & \multirow{2}{*}{$\begin{array}{l}\text { Study } \\
7\end{array}$} & \multicolumn{2}{|c|}{ IPF (D/T) } & \multicolumn{2}{|c|}{$\begin{array}{l}\text { Control Group } \\
(D / T)\end{array}$} & \multirow{2}{*}{$\begin{array}{l}\text { OR } \\
1.43\end{array}$} & \multirow{2}{*}{$\begin{array}{l}95 \% \mathrm{Cl} \\
1.16- \\
1.76\end{array}$} & \multirow{2}{*}{$\begin{array}{l}P \\
\text { value } \\
P= \\
0.0007\end{array}$} & \multirow{2}{*}{$\begin{array}{l}\text { Heterogeneity } \\
R^{2}=55 \%\end{array}$} \\
\hline & & 698 & 4891 & 2142 & 18420 & & & & \\
\hline $\begin{array}{l}\text { Smoking status matched } \\
\text { in both groups }[8-10,25]\end{array}$ & 4 & 203 & 1581 & 598 & 6138 & 1.52 & $\begin{array}{l}1.05- \\
2.19\end{array}$ & $\begin{array}{l}P= \\
0.02\end{array}$ & $R=65 \%$ \\
\hline $\begin{array}{l}\text { Control groups made up of } \\
\text { general population[7, 10, } \\
25-28]\end{array}$ & 6 & 721 & 4795 & 2135 & 18212 & 1.49 & $\begin{array}{l}1.19- \\
1.88\end{array}$ & $\begin{array}{l}P= \\
0.0007\end{array}$ & $P^{2}=66 \%$ \\
\hline $\begin{array}{l}\text { Control group with } \\
\text { pulmonary diseases }[8,9]\end{array}$ & 2 & 24 & 201 & 23 & 620 & 2.23 & $\begin{array}{l}0.56- \\
8.88\end{array}$ & $\begin{array}{l}P= \\
0.25\end{array}$ & $R=79 \%$ \\
\hline Healthy control group[24] & 1 & 30 & 100 & 50 & 263 & 1.83 & $\begin{array}{l}1.08- \\
3.09\end{array}$ & $\ldots$ & $\ldots$ \\
\hline Community controls[7, 24] & 2 & 47 & 152 & 71 & 447 & 2.50 & $\begin{array}{l}1.24- \\
5.06\end{array}$ & $\begin{array}{l}P= \\
0.01\end{array}$ & $R^{2}=59 \%$ \\
\hline $\begin{array}{l}\text { Hospital controls[8-10, } \\
25-28]\end{array}$ & 7 & 728 & 4944 & 2137 & 18648 & 1.47 & $\begin{array}{l}1.17- \\
1.84\end{array}$ & $\begin{array}{l}P= \\
0.008\end{array}$ & $R=61 \%$ \\
\hline $\begin{array}{l}\text { Diagnosis of IPF based on } \\
\text { ATS/ERS criteria[7-9, 24- } \\
\text { 26] }\end{array}$ & 6 & 170 & 857 & 402 & 3080 & 2.09 & $\begin{array}{l}1.34- \\
3.29\end{array}$ & $\begin{array}{l}P= \\
0.001\end{array}$ & $P=66 \%$ \\
\hline $\begin{array}{l}\text { Diagnosis of DM based on } \\
\text { FBG }[7,9,25,26,28]\end{array}$ & 5 & 193 & 761 & 395 & 2872 & 2.38 & $\begin{array}{l}1.43- \\
3.97\end{array}$ & $\begin{array}{l}P= \\
0.0009\end{array}$ & $P^{2}=72 \%$ \\
\hline $\begin{array}{l}\text { Diagnosis of DM based on } \\
\text { subjective methods }[8,24]\end{array}$ & 2 & 43 & 204 & 57 & 323 & 1.62 & $\begin{array}{l}1.02- \\
2.58\end{array}$ & $\begin{array}{l}P= \\
0.04\end{array}$ & $R=0$ \\
\hline
\end{tabular}

\section{Bias Analysis}

All elements that could induce IPF were considered as potential sources of biases. Firstly, cigarette smoking is a known risk factor for IPF[29] and in the five included studies[7, 24, 26-28], smokers or ex-smokers were much more in case groups than in controls. In the following subgroup analysis (Table 2), when we selected the other four studies[8-10, 25] in which the smoking habits between case and control groups were similar, the association remained statistically significant (OR: 1.52, 95\% Cl: 1.05-2.19; $P=0.02)$, which coincided with the outcome of the meta-regression (Fig. 5, $\mathrm{P}=$ $0.351)$, suggesting that smoking was unlikely to distort the final results. Next, considering that age and gender are related to IPF despite inexplicable reasons[6], seven studies[7, 8, 10, 24-27] in which these two factors were wellbalanced were used to inform another analysis, yet again concluding that DM correlated with IPF (OR: $1.43,95 \% \mathrm{Cl}$ : 1.16-1.76; $P=0.0007)$. Still, there remained two potential sources of biases that the included literatures did not sufficiently address (Table 3). In light of a multicenter case-control study[30], environmental exposure was likely responsible for the incidence of IPF, which has been gradually acknowledged in recent years. Though three studies[8, 9 , $24]$ took this into consideration, unfortunately, only one study matched case and control groups. However, in that single study[9], DM was proven to be the most dangerous factor for IPF in the logistic regression model (OR: 4.3, 95\% Cl: 1.99.8). Genetic factor, which was considered as one of the covariates according to the guidelines by ATS/ERS[6], was not 
referred to in any study except one[24]. Additionally, case and control groups in this study were regrettably unmatched. Thus, the impact it had on final conclusions was difficult to evaluate. Publication bias existed $(P=0.016<0.05)$ judged by the Egger's test (Fig. 6).

Table 3

Potential Sources of Bias

\begin{tabular}{|c|c|c|c|c|}
\hline \multirow{2}{*}{$\begin{array}{l}\text { Study } \\
\text { Enomoto et al[7] } 2003\end{array}$} & \multicolumn{2}{|c|}{ Environmental Exposure (IG/CG) } & \multicolumn{2}{|c|}{ Family IPF (IG/CG) } \\
\hline & Not stated & Not stated & $\begin{array}{l}\text { Not } \\
\text { stated }\end{array}$ & $\begin{array}{l}\text { Not } \\
\text { stated }\end{array}$ \\
\hline Miyake et al[8] 2005 & $31.7 \%$ & $8.3 \%$ & $\begin{array}{l}\text { Not } \\
\text { stated }\end{array}$ & $\begin{array}{l}\text { Not } \\
\text { stated }\end{array}$ \\
\hline Gribbin et al[10] 2009 & Not stated & Not stated & $\begin{array}{l}\text { Not } \\
\text { stated }\end{array}$ & $\begin{array}{l}\text { Not } \\
\text { stated }\end{array}$ \\
\hline Ma.C et al[9] 2010 & $\begin{array}{l}\text { dust } 56.7 \% \\
\text { smoke } 66.0 \% \\
\text { chemicals } 28.9 \%\end{array}$ & $\begin{array}{l}\text { dust } 52.1 \% \\
\text { smoke } 69.3 \% \\
\text { chemicals } 21.4 \%\end{array}$ & $\begin{array}{l}\text { Not } \\
\text { stated }\end{array}$ & $\begin{array}{l}\text { Not } \\
\text { stated }\end{array}$ \\
\hline $\begin{array}{l}\text { Garcia-Sancho et al[24] } \\
2011\end{array}$ & $\begin{array}{l}\text { Matched by place of } \\
\text { residence }\end{array}$ & $\begin{array}{l}\text { Matched by place of } \\
\text { residence }\end{array}$ & $20 \%$ & $8.7 \%$ \\
\hline Kim et al[25] 2015 & Not stated & Not stated & $\begin{array}{l}\text { Not } \\
\text { stated }\end{array}$ & $\begin{array}{l}\text { Not } \\
\text { stated }\end{array}$ \\
\hline Dalleywater et al[27] 2015 & Not stated & Not stated & $\begin{array}{l}\text { Not } \\
\text { stated }\end{array}$ & $\begin{array}{l}\text { Not } \\
\text { stated }\end{array}$ \\
\hline Zhong et al[28] 2016 & Not stated & Not stated & $\begin{array}{l}\text { Not } \\
\text { stated }\end{array}$ & $\begin{array}{l}\text { Not } \\
\text { stated }\end{array}$ \\
\hline Xu et al[26] 2020 & Not stated & Not stated & $\begin{array}{l}\text { Not } \\
\text { stated }\end{array}$ & $\begin{array}{l}\text { Not } \\
\text { stated }\end{array}$ \\
\hline
\end{tabular}

\section{Discussion}

\section{Main Findings and Clinical Inspiration}

In the present meta-analysis, it was revealed that the prevalence of diabetes was increased markedly in IPF cases compared with controls, which suggests that DM is an independent risk factor for IPF. However, the conclusion lacks persuasiveness for that all of the included studies are retrospective case-control studies which are easily affected by recall bias. Additionally, the interpretation of the outcome is in the limitation of the significant heterogeneity, which could not be satisfactorily explained.

Interestingly, a recent review[31] clarified the common features between IPF and pulmonary complications in diabetics. These include clinical characteristics (injury of lung function mainly manifested in decline in FVC, FEV1[32] and $\mathrm{DL}_{\mathrm{CO}}$ [33-37]), HRCT imaging (the frequently presented UIP pattern[38, 39]) and histopathological changes (thickening of the basal lamina of lung capillaries[40,41], increased amount of collagen in the alveolar walls[42], etc), all of which indicated that IPF and diabetes are closely related. This conclusion validated the findings of our meta-analysis as well 
as equipping them with biological plausibility. However, even if the manifestations are proven to be pulmonary fibrosis, it is still unclear whether a causal relationship exists between DM and IPF.

Therefore, understanding the exact pathological mechanisms is crucial; namely, how persistent hyperglycemia, a known characteristic of diabetes, gradually contributes to the pulmonary lesions. Studies found that a high glucose concentration could result in nonenzymatic glycation with the ultimate formation of advanced glycation end products (AGEs), which may target type IV collagen in the alveolar basement membrane, thicken the basal lamina both in epithelial and capillary of alveoli and eventually lead to a decrease in pulmonary elasticity and compliance[43-45]. This hypothesis has become recognized as an explanation for the pathological abnormalities of interest, including injured pulmonary function in diabetic individuals. Furthermore, some investigators hold the view that oxidative stress (OS), which refers to an imbalance between free radicals and antioxidants in the body, is intimately connected with the onset of IPF. On one hand, OS can directly enhance nonenzymatic glycation[46], but on another, OS participates in the activation of nuclear factor-kappaB (NF-kB)[47], which is presumably the central part in initiating processes of alveolitis. One study[48] shows that inhibiting the activation of the transcription factor NF-KB could reduce lung injury and fibrosis. Hürdag $C$ et al.[49] discovered that OS could decrease superoxide dismutase (SOD), increase nitric oxide synthase (NOS), and contribute to overproduction of nitric oxide (NO) and peroxynitrite ( $\mathrm{ONOO}^{-}$), potentially giving rise to damage of lung tissue and ultimately pulmonary fibrosis[50, 51]. In addition, inflammatory cytokines play a crucial role, among which transforming growth factor-beta1 (TGF- $\beta 1$ ) attracts the most attention. TGF- $\beta 1$ was found overexpressed in hyperglycemia, which has been documented to promote proliferation and differentiation of fibroblasts, activation of myofibroblasts and deposition of extracellular matrix (ECM)[52-56], all of which will eventually bring about lung fibrosis.

Although the possible pathophysiologic mechanisms do explain the disease process, we acknowledge that multiple factors may induce pulmonary fibrosis and that it is also indeterminate to what extend IPF is affected by diabetes. Thus, to solidify the association between DM and IPF, the beneficial effect of antidiabetic therapy should be established. Currently, pirfenidone and nintedanib are the only options with a proven impact on pulmonary fibrosis. However, gastrointestinal adverse events are common[57-59] and IPF will progress inevitably in all patients, so more effective measures are still necessitated. The discovery that metformin is effective on reversal of pulmonary fibrosis[11-15, 60] brings a new dawn for IPF. Unfortunately, no clinical placebo-controlled trials have ever been attempted, which are less likely to be realized, in consideration of the application of antifibrotic drugs with definite efficacy (pirfenidone and nintedanib). Consequently, trials that place more importance on combination therapies with metformin and pirfenidone/nintedanib are essential in the future; considerations may include whether the effect of antifibrotic treatment will be improved, adding metformin on the basis of original dose of pirfenidone/nintedanib, or whether the effect will be maintained, combining metformin and low-dose pirfenidone/nintedanib, for the sake of reducing adverse reactions. Besides, since persistent hyperglycemia may promote the occurrence and development of pulmonary fibrosis, further research should investigate the suitable threshold of blood glucose for IPF or ILD patients and whether timely and effective hypoglycemic therapy would prevent the incidence or progression of the disease. We expect such findings could further strengthen the evidence linking IPF with DM.

\section{Strengths and Limitations}

In our meta-analysis, we screened literatures in strict accordance with inclusion and exclusion criteria, designed the study with high quality, and finally demonstrated that DM and IPF are very likely interrelated. This study provides insight that future studies may employ in developing curative antifibrotic treatments and improving the prognosis of IPF patients. Nevertheless, there remain several limitations in our study. Firstly, the heterogeneity was significant, and a reasonable interpretation is still absent. The wide range of prevalence of DM (from $10-61 \%$ in IPF groups and from 3$43 \%$ in control groups) in the studies has attracted our attention, which could be responsible for major heterogeneity; we 
assumed this to be secondary to multiple factors including diagnostic criteria of diabetes (subjective or objective methods) and IPF (discrepancy among different editions), selection of populations (with or without underlying diseases), and regional differences. However, the internal causal relationship has not been established to date. Secondly, given that the result is based on case-control studies, which are susceptible to confounding factors, the potential sources of biases have always been a focus. Even though influence of smoking, age, and gender was ruled out in our bias analysis, other covariates such as genetic factor might also cloud the association between DM and IPF, especially considering that at least $30 \%$ of patients have predisposing genetic factors which could increase the risk of pulmonary fibrosis[61-63]. Besides, two studies[10, 27] from the UK are based on the THIN database (in Gribbin's research, IPF cases are from the period 1991-2003 while in Dalleywat's, cases are from 2000-2011), which may be one of the contributory reasons of the notable publication bias, and repeated cases might cause type I errors (false positive conclusions).

\section{Conclusion}

The association between diabetes and IPF was briefly referred to in ATS/ERS clinical practice guideline updated in 2011[64], but not in the newest edition[6] perhaps owing to the contradiction of existing evidence. Our study favors the hypothesis that DM and IPF are associated, based on the present meta-analysis and systematic review. However, the curative effect of antidiabetic therapy in IPF remains to be further confirmed and the risk of disease progression that combination therapies might carry is worthy of caution as well.

\section{Abbreviations}

ATS, American Thoracic Society

DLCO, diffusion capacity for carbon monoxide of the lung

DM, diabetes mellitus

ERS, European Respiratory Society

FEV1, forced expiratory volume in the first second

FVC, forced vital capcacit

HRCT, High-Resolution Computed Tomography

ILD, interstitial lung disease

IPF, idiopathic pulmonary fibrosis

NF-Kb, nuclear factor-kappaB

NOS, Newcastle-Ottawa Scale

TGF- $\beta 1$, transforming growth factor- $\beta 1$

THIN, The Health Improvement Network

TSA, trial sequential analysis

UIP, usual interstitia pneumonia 


\section{Declarations}

Ethics approval and consent to participate:

Not applicable.

Consent for publication:

Not applicable.

Availability of data and materials:

All data generated or analysed during this study are included in these published article[7-10, 24-28].

Competing interests:

All of the authors have no competing interests.

Funding:

This study was supported by National Nature Science Foundation of China (NO. 82074358).

Author's contributions:

Xianmei Zhou and Hailang He contributed conception, design, and quality control of the study. Le Bai was in charge of literature search, data extraction, and manuscript writing. Li Zhang and Tingyu Pan helped with data extraction. Wei Wang and Dian Wang managed data analysis. Cassidy Turner edited the language.

Acknowledgements:

Not applicable.

\section{References}

1. Raghu G, Chen SY, Hou Q, Yeh WS, Collard HR: Incidence and prevalence of idiopathic pulmonary fibrosis in US adults 18-64 years old. Eur Respir J 2016, 48:179-186.

2. Strongman H, Kausar I, Maher TJAit: Incidence, Prevalence, and Survival of Patients with Idiopathic Pulmonary Fibrosis in the UK. 2018, 35:724-736.

3. Behr J, Prasse A, Wirtz H, Koschel D, Pittrow D, Held M, Klotsche J, Andreas S, Claussen M, Grohé C, et al: Survival and course of lung function in the presence or absence of antifibrotic treatment in patients with idiopathic pulmonary fibrosis: long-term results of the INSIGHTS-IPF registry. Eur Respir J 2020, 56.

4. Marshall RP, McAnulty RJ, Laurent GJ: The pathogenesis of pulmonary fibrosis: is there a fibrosis gene? Int J Biochem Cell Biol 1997, 29:107-120.

5. Pardo A, Selman M: The Interplay of the Genetic Architecture, Aging, and Environmental Factors in the Pathogenesis of Idiopathic Pulmonary Fibrosis. Am J Respir Cell Mol Biol 2020.

6. Raghu G, Remy-Jardin M, Myers JL, Richeldi L, Ryerson CJ, Lederer DJ, Behr J, Cottin V, Danoff SK, Morell F, et al: Diagnosis of Idiopathic Pulmonary Fibrosis. An Official ATS/ERS/JRS/ALAT Clinical Practice Guideline. Am J Respir Crit Care Med 2018, 198:e44-e68. 
7. Enomoto T, Usuki J, Azuma A, Nakagawa T, Kudoh S: Diabetes mellitus may increase risk for idiopathic pulmonary fibrosis. Chest 2003, 123:2007-2011.

8. Miyake Y, Sasaki S, Yokoyama T, Chida K, Azuma A, Suda T, Kudoh S, Sakamoto N, Okamoto K, Kobashi G, et al: Case-control study of medical history and idiopathic pulmonary fibrosis in Japan. Respirology 2005, 10:504-509.

9. García-Sancho Figueroa MC, Carrillo G, Pérez-Padilla R, Fernández-Plata MR, Buendía-Roldán I, Vargas MH, Selman M: Risk factors for idiopathic pulmonary fibrosis in a Mexican population. A case-control study. Respir Med 2010, 104:305-309.

10. Gribbin J, Hubbard R, Smith C: Role of diabetes mellitus and gastro-oesophageal reflux in the aetiology of idiopathic pulmonary fibrosis. Respir Med 2009, 103:927-931.

11. Gamad N, Malik S, Suchal K, Vasisht S, Tomar A, Arava S, Arya DS, Bhatia J: Metformin alleviates bleomycininduced pulmonary fibrosis in rats: Pharmacological effects and molecular mechanisms. Biomed Pharmacother 2018, 97:1544-1553.

12. Rangarajan S, Bone NB, Zmijewska AA, Jiang S, Park DW, Bernard K, Locy ML, Ravi S, Deshane J, Mannon RB, et al: Metformin reverses established lung fibrosis in a bleomycin model. Nat Med 2018, 24:1121-1127.

13. Wang Y, Lin C, Han R, Lu C, Li L, Hu C, Feng M, Chen H, He Y: Metformin attenuates TGF- $\beta 1$-induced pulmonary fibrosis through inhibition of transglutaminase 2 and subsequent TGF- $\beta$ pathways. 3 Biotech 2020, 10:287.

14. Xiao H, Huang X, Wang S, Liu Z, Dong R, Song D, Dai H: Metformin ameliorates bleomycin-induced pulmonary fibrosis in mice by suppressing IGF-1. Am J Trans/ Res 2020, 12:940-949.

15. Kheirollahi V, Wasnick RM, Biasin V, Vazquez-Armendariz Al, Chu X, Moiseenko A, Weiss A, Wilhelm J, Zhang JS, Kwapiszewska G, et al: Metformin induces lipogenic differentiation in myofibroblasts to reverse lung fibrosis. Nat Commun 2019, 10:2987.

16. Spagnolo P, Kreuter M, Maher TM, Wuyts W, Bonella F, Corte TJ, Kopf S, Weycker D, Kirchgaessler KU, Ryerson CJ: Metformin Does Not Affect Clinically Relevant Outcomes in Patients with Idiopathic Pulmonary Fibrosis. Respiration 2018, 96:314-322.

17. Kreuter M, Lederer DJ, Cottin V, Kahn N, Ley B, Vancheri C, Weycker D, Atwood M, Kirchgaessler KU, Ryerson CJ: Concomitant medications and clinical outcomes in idiopathic pulmonary fibrosis. Eur Respir J 2019, 54.

18. Stroup DF, Berlin JA, Morton SC, Olkin I, Williamson GD, Rennie D, Moher D, Becker BJ, Sipe TA, Thacker SB: Metaanalysis of observational studies in epidemiology: a proposal for reporting. Meta-analysis Of Observational Studies in Epidemiology (MOOSE) group. Jama 2000, 283:2008-2012.

19. Moher D, Liberati A, Tetzlaff J, Altman DG: Preferred reporting items for systematic reviews and meta-analyses: the PRISMA statement. J Clin Epidemio/ 2009, 62:1006-1012.

20. Wells GA SB, O'Connell D, et al: The Newcastle-Ottawa Scale (NOS) for assessing the quality of nonrandomised studies in meta-analyses.

21. Brok J, Thorlund K, Gluud C, Wetterslev J: Trial sequential analysis reveals insufficient information size and potentially false positive results in many meta-analyses. J Clin Epidemio/ 2008, 61:763-769.

22. Brok J, Thorlund K, Wetterslev J, Gluud C: Apparently conclusive meta-analyses may be inconclusive-Trial sequential analysis adjustment of random error risk due to repetitive testing of accumulating data in apparently conclusive neonatal meta-analyses. Int J Epidemio/ 2009, 38:287-298.

23. Egger M, Davey Smith G, Schneider M, Minder C: Bias in meta-analysis detected by a simple, graphical test. $B m j$ 1997, 315:629-634.

24. García-Sancho C, Buendía-Roldán I, Fernández-Plata MR, Navarro C, Pérez-Padilla R, Vargas MH, Loyd JE, Selman M: Familial pulmonary fibrosis is the strongest risk factor for idiopathic pulmonary fibrosis. Respir Med 2011, 
105:1902-1907.

25. Kim WY, Mok Y, Kim GW, Baek SJ, Yun YD, Jee SH, Kim DS: Association between idiopathic pulmonary fibrosis and coronary artery disease: a case-control study and cohort analysis. Sarcoidosis Vasc Diffuse Lung Dis 2015, 31:289296.

26. Xu J, shao-xia L: Study on association of idiopathic pulmonary fibrosis with diabetes mellitus. J Medical Forum 2020, 41:58-62.

27. Dalleywater W, Powell HA, Hubbard RB, Navaratnam V: Risk factors for cardiovascular disease in people with idiopathic pulmonary fibrosis: a population-based study. Chest 2015, 147:150-156.

28. Xie Z, He Y, Sun Y, Lin Z, Yang M, Liu Q, Liu S: Association between pulmonary fibrosis and osteoporosis in the elderly people: A case-control study. Medicine (Baltimore) 2016, 95:e5239.

29. Behr J, Kreuter M, Hoeper MM, Wirtz H, Klotsche J, Koschel D, Andreas S, Claussen M, Grohé C, Wilkens H, et al: Management of patients with idiopathic pulmonary fibrosis in clinical practice: the INSIGHTS-IPF registry. Eur Respir J 2015, 46:186-196.

30. Baumgartner KB, Samet JM, Coultas DB, Stidley CA, Hunt WC, Colby TV, Waldron JA: Occupational and environmental risk factors for idiopathic pulmonary fibrosis: a multicenter case-control study. Collaborating Centers. Am J Epidemiol 2000, 152:307-315.

31. Wang D, Ma Y, Tong X, Zhang Y, Fan H: Diabetes Mellitus Contributes to Idiopathic Pulmonary Fibrosis: A Review From Clinical Appearance to Possible Pathogenesis. Front Public Health 2020, 8:196.

32. Yeh HC, Punjabi NM, Wang NY, Pankow JS, Duncan BB, Cox CE, Selvin E, Brancati FL: Cross-sectional and prospective study of lung function in adults with type 2 diabetes: the Atherosclerosis Risk in Communities (ARIC) study. Diabetes Care 2008, 31:741-746.

33. Marvisi M, Bartolini L, del Borrello P, Brianti M, Marani G, Guariglia A, Cuomo A: Pulmonary function in non-insulindependent diabetes mellitus. Respiration 2001, 68:268-272.

34. Davis WA, Knuiman M, Kendall P, Grange V, Davis TM: Glycemic exposure is associated with reduced pulmonary function in type 2 diabetes: the Fremantle Diabetes Study. Diabetes Care 2004, 27:752-757.

35. Sonoda N, Morimoto A, Tatsumi Y, Asayama K, Ohkubo T, Izawa S, Ohno Y: A prospective study of the impact of diabetes mellitus on restrictive and obstructive lung function impairment: The Saku study. Metabolism 2018, 82:58-64.

36. van den Borst B, Gosker HR, Zeegers MP, Schols AM: Pulmonary function in diabetes: a metaanalysis. Chest 2010, 138:393-406.

37. Klein OL, Krishnan JA, Glick S, Smith LJ: Systematic review of the association between lung function and Type 2 diabetes mellitus. Diabet Med 2010, 27:977-987.

38. Hu Y, Ma Z, Guo Z, Zhao F, Wang Y, Cai L, Yang J: Type 1 diabetes mellitus is an independent risk factor for pulmonary fibrosis. Cell Biochem Biophys 2014, 70:1385-1391.

39. Kim YJ, Park JW, Kyung SY, Lee SP, Chung MP, Kim YH, Lee JH, Kim YC, Ryu JS, Lee HL, et al: Clinical characteristics of idiopathic pulmonary fibrosis patients with diabetes mellitus: the national survey in Korea from 2003 to 2007. J Korean Med Sci 2012, 27:756-760.

40. Weynand B, Jonckheere A, Frans A, Rahier J: Diabetes mellitus induces a thickening of the pulmonary basal lamina. Respiration 1999, 66:14-19.

41. Watanabe K, Senju S, Toyoshima H, Yoshida M: Thickness of the basement membrane of bronchial epithelial cells in lung diseases as determined by transbronchial biopsy. Respir Med 1997, 91:406-410. 
42. Fariña J, Furió V, Fernandez-Aceñero MJ, Muzas MA: Nodular fibrosis of the lung in diabetes mellitus. Virchows Arch 1995, 427:61-63.

43. Vlassara H, Bucala R, Striker L: Pathogenic effects of advanced glycosylation: biochemical, biologic, and clinical implications for diabetes and aging. Lab Invest 1994, 70:138-151.

44. McKeever TM, Weston PJ, Hubbard R, Fogarty A: Lung function and glucose metabolism: an analysis of data from the Third National Health and Nutrition Examination Survey. Am J Epidemiol 2005, 161:546-556.

45. Schmidt AM, Hori O, Cao R, Yan SD, Brett J, Wautier JL, Ogawa S, Kuwabara K, Matsumoto M, Stern D: RAGE: a novel cellular receptor for advanced glycation end products. Diabetes 1996, 45 Suppl 3:S77-80.

46. Oztay F, Kandil A, Gurel E, Ustunova S, Kapucu A, Balci H, Akgun-Dar K, Demirci C: The relationship between nitric oxide and leptin in the lung of rat with streptozotocin-induced diabetes. Cell Biochem Funct 2008, 26:162-171.

47. Li KC, Ho YL, Chen CY, Hsieh WT, Chang YS, Huang GJ: Lobeline improves acute lung injury via nuclear factor-kBsignaling pathway and oxidative stress. Respir Physiol Neurobiol 2016, 225:19-30.

48. Gurujeyalakshmi G, Wang Y, Giri SN: Taurine and niacin block lung injury and fibrosis by down-regulating bleomycin-induced activation of transcription nuclear factor-kappaB in mice. J Pharmacol Exp Ther 2000, 293:8290.

49. Hürdağ C, Uyaner I, Gürel E, Utkusavas A, Atukeren P, Demirci C: The effect of alpha-lipoic acid on NOS dispersion in the lung of streptozotocin-induced diabetic rats. J Diabetes Complications 2008, 22:56-61.

50. Schwartz MD, Moore EE, Moore FA, Shenkar R, Moine P, Haenel JB, Abraham E: Nuclear factor-kappa B is activated in alveolar macrophages from patients with acute respiratory distress syndrome. Crit Care Med 1996, 24:12851292.

51. He Z, Li B, Yu L, Liu Q, Zhong N, Ran P: Suppression of oxidant-induced glutathione synthesis by erythromycin in human bronchial epithelial cells. Respiration 2008, 75:202-209.

52. Tarantal AF, Chen H, Shi TT, Lu CH, Fang AB, Buckley S, Kolb M, Gauldie J, Warburton D, Shi W: Overexpression of transforming growth factor-beta1 in fetal monkey lung results in prenatal pulmonary fibrosis. Eur Respir J 2010, 36:907-914.

53. Border WA, Noble NA: Transforming growth factor beta in tissue fibrosis. N Engl J Med 1994, 331:1286-1292.

54. Fernandez IE, Eickelberg O: The impact of TGF- $\beta$ on lung fibrosis: from targeting to biomarkers. Proc Am Thorac Soc 2012, 9:111-116.

55. Zhang YE: Non-Smad Signaling Pathways of the TGF- $\beta$ Family. Cold Spring Harb Perspect Bio/ 2017, 9.

56. Massagué J: TGF $\beta$ signalling in context. Nat Rev Mol Cell Biol 2012, 13:616-630.

57. Noble PW, Albera C, Bradford WZ, Costabel U, Glassberg MK, Kardatzke D, King TE, Jr., Lancaster L, Sahn SA, Szwarcberg J, et al: Pirfenidone in patients with idiopathic pulmonary fibrosis (CAPACITY): two randomised trials. Lancet 2011, 377:1760-1769.

58. King TE, Jr., Bradford WZ, Castro-Bernardini S, Fagan EA, Glaspole I, Glassberg MK, Gorina E, Hopkins PM, Kardatzke D, Lancaster $\mathrm{L}$, et al: A phase 3 trial of pirfenidone in patients with idiopathic pulmonary fibrosis. $N$ Engl J Med 2014, 370:2083-2092.

59. Galli JA, Pandya A, Vega-Olivo M, Dass C, Zhao H, Criner GJ: Pirfenidone and nintedanib for pulmonary fibrosis in clinical practice: Tolerability and adverse drug reactions. Respirology 2017, 22:1171-1178.

60. Xie N, Tan Z, Banerjee S, Cui H, Ge J, Liu RM, Bernard K, Thannickal VJ, Liu G: Glycolytic Reprogramming in Myofibroblast Differentiation and Lung Fibrosis. Am J Respir Crit Care Med 2015, 192:1462-1474.

61. Allen RJ, Porte J, Braybrooke R, Flores C, Fingerlin TE, Oldham JM, Guillen-Guio B, Ma SF, Okamoto T, John AE, et al: Genetic variants associated with susceptibility to idiopathic pulmonary fibrosis in people of European ancestry: 
a genome-wide association study. Lancet Respir Med 2017, 5:869-880.

62. Fingerlin TE, Murphy E, Zhang W, Peljto AL, Brown KK, Steele MP, Loyd JE, Cosgrove GP, Lynch D, Groshong S, et al: Genome-wide association study identifies multiple susceptibility loci for pulmonary fibrosis. Nat Genet 2013, 45:613-620.

63. Peljto AL, Zhang Y, Fingerlin TE, Ma SF, Garcia JG, Richards TJ, Silveira LJ, Lindell KO, Steele MP, Loyd JE, et al: Association between the MUC5B promoter polymorphism and survival in patients with idiopathic pulmonary fibrosis. Jama 2013, 309:2232-2239.

64. Raghu G, Collard HR, Egan JJ, Martinez FJ, Behr J, Brown KK, Colby TV, Cordier JF, Flaherty KR, Lasky JA, et al: An official ATS/ERS/JRS/ALAT statement: idiopathic pulmonary fibrosis: evidence-based guidelines for diagnosis and management. Am J Respir Crit Care Med 2011, 183:788-824.

65. American Thoracic Society. Idiopathic pulmonary fibrosis: diagnosis and treatment. International consensus statement. American Thoracic Society (ATS), and the European Respiratory Society (ERS). Am J Respir Crit Care Med 2000, 161:646-664.

\section{Figures}



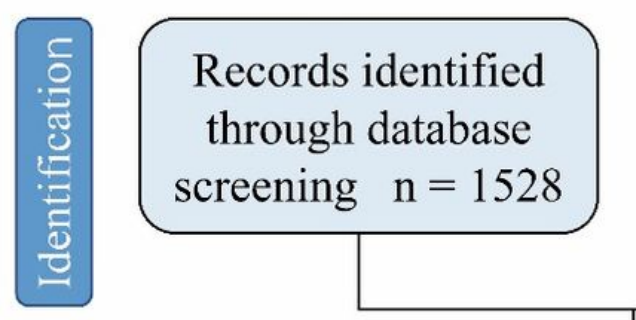

Additional records identified through other scources $\mathrm{n}=0$

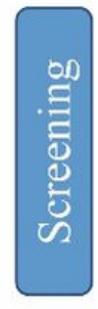

Title and abstract screened $n=462$

Duplicates removed $\mathrm{n}=1066$

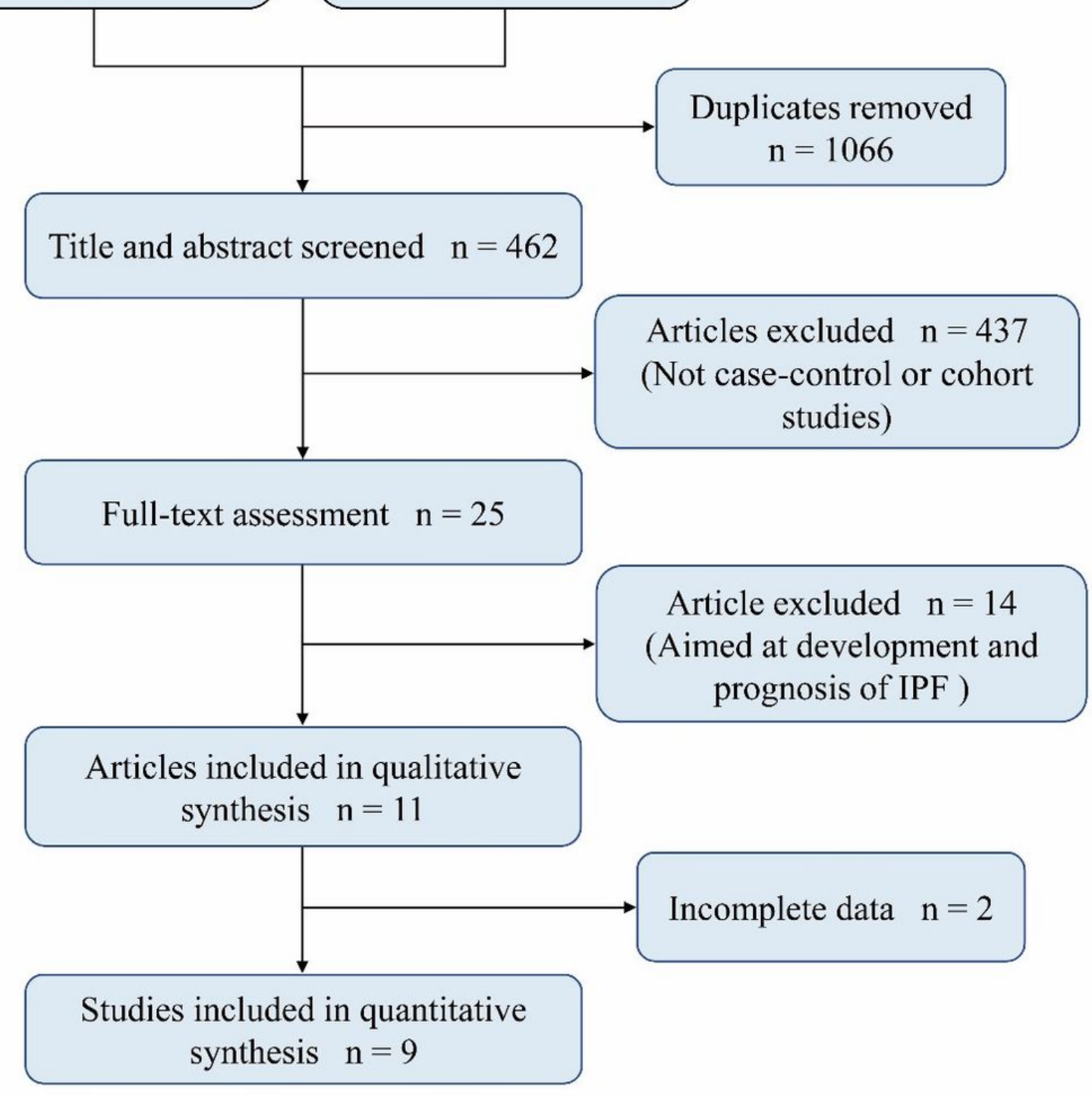

Figure 1

The flow diagram of study selection 


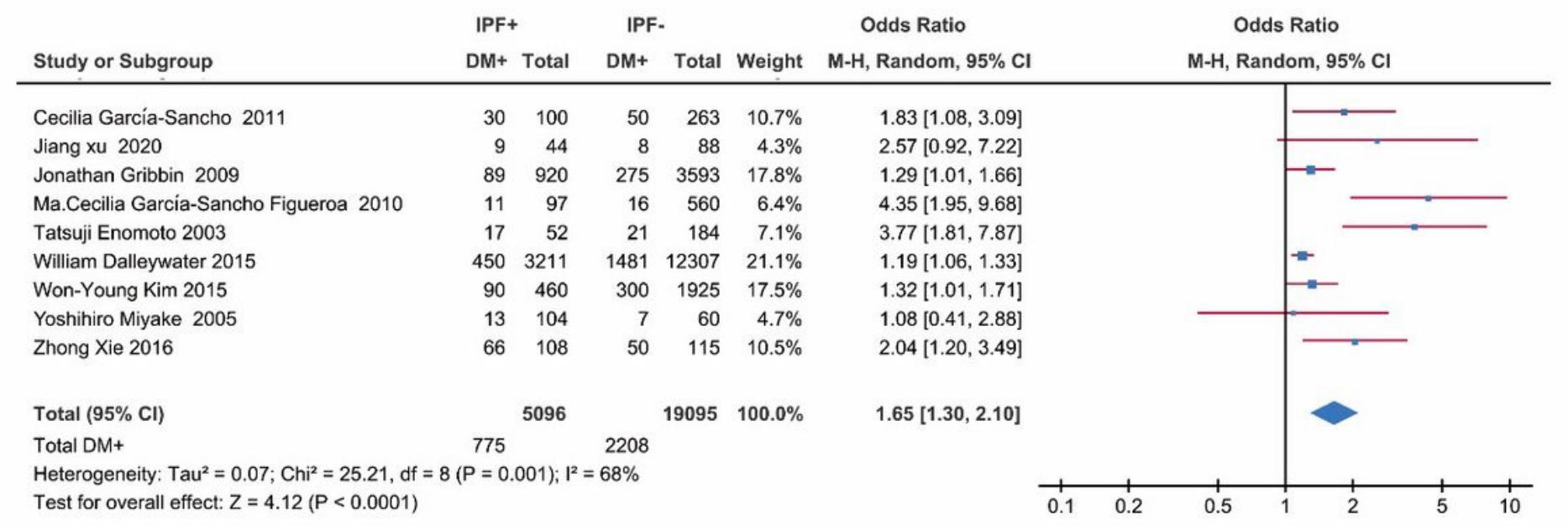

\section{Figure 2}

Forest plot of individual and pooled effect of odds ratio for DM in IPF. IPF = Idiopathic Pulmonary Fibrosis. DM = Diabetes Mellitus. $\mathrm{M}-\mathrm{H}=$ Mantel-Haenszel.

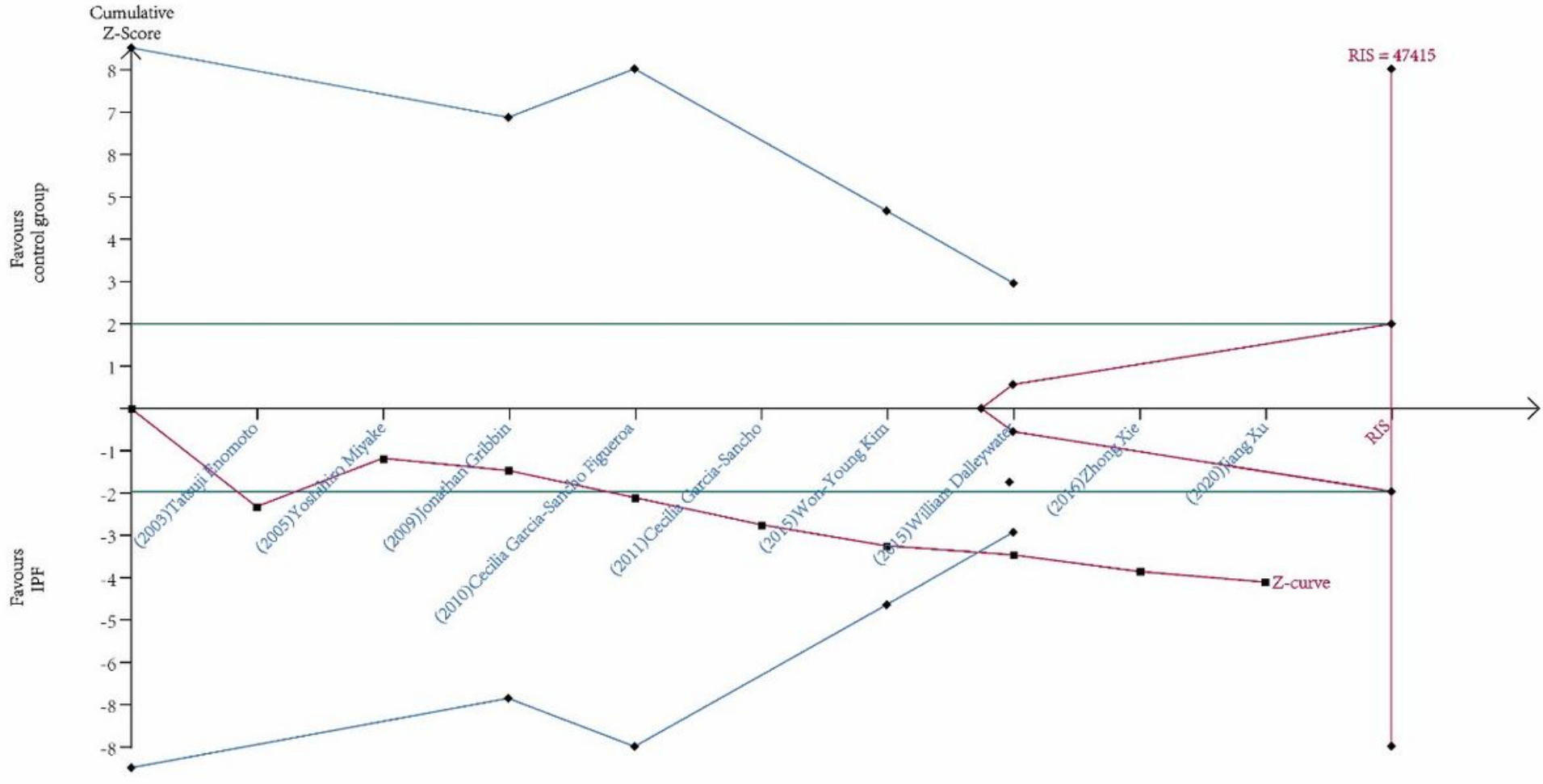

\section{Figure 3}

Trial sequential analysis for the 9 studies providing the calculation of correlativity between DM and IPF. The diversityadjusted required information size (RIS) was 47415 patients, with $a=5 \%$ (two-side), power of $80 \%$, relative risk reduction of $35 \%$ and incidence of $3 \%$ in the control arm. The cumulative $Z$ curve got across both the conventional boundary (green line) and the trial sequential monitoring boundary (blue line), indicating that the information size was sufficient and the outcome was reliable. 


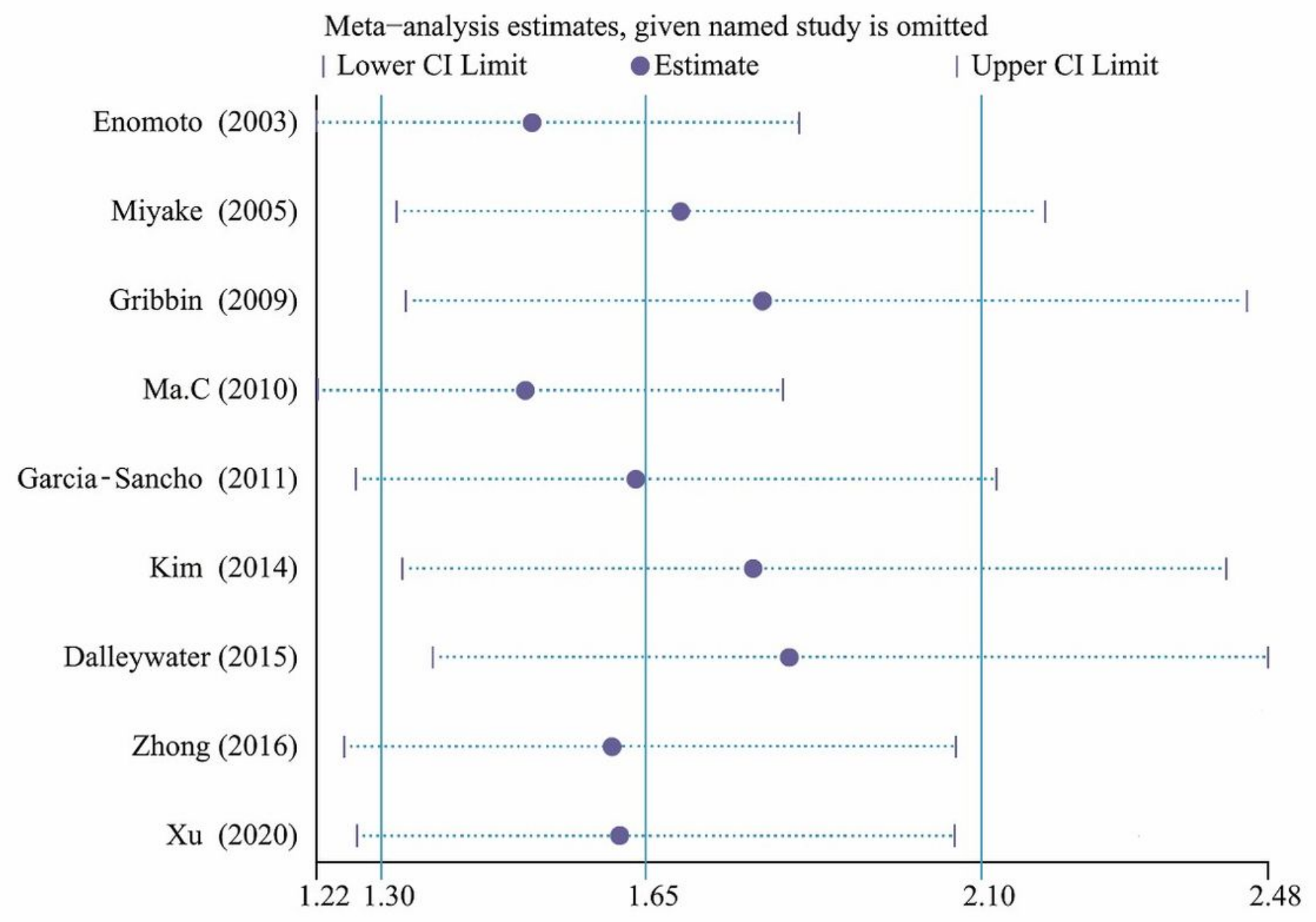

\section{Figure 4}

Sensitivity analyses of the primary meta-analysis. Every odds ratio was located between 1.30 and 2.10 while none of $95 \%$ confidence intervals crossed the invalid line " 1 ", signifying that the result was stable. 


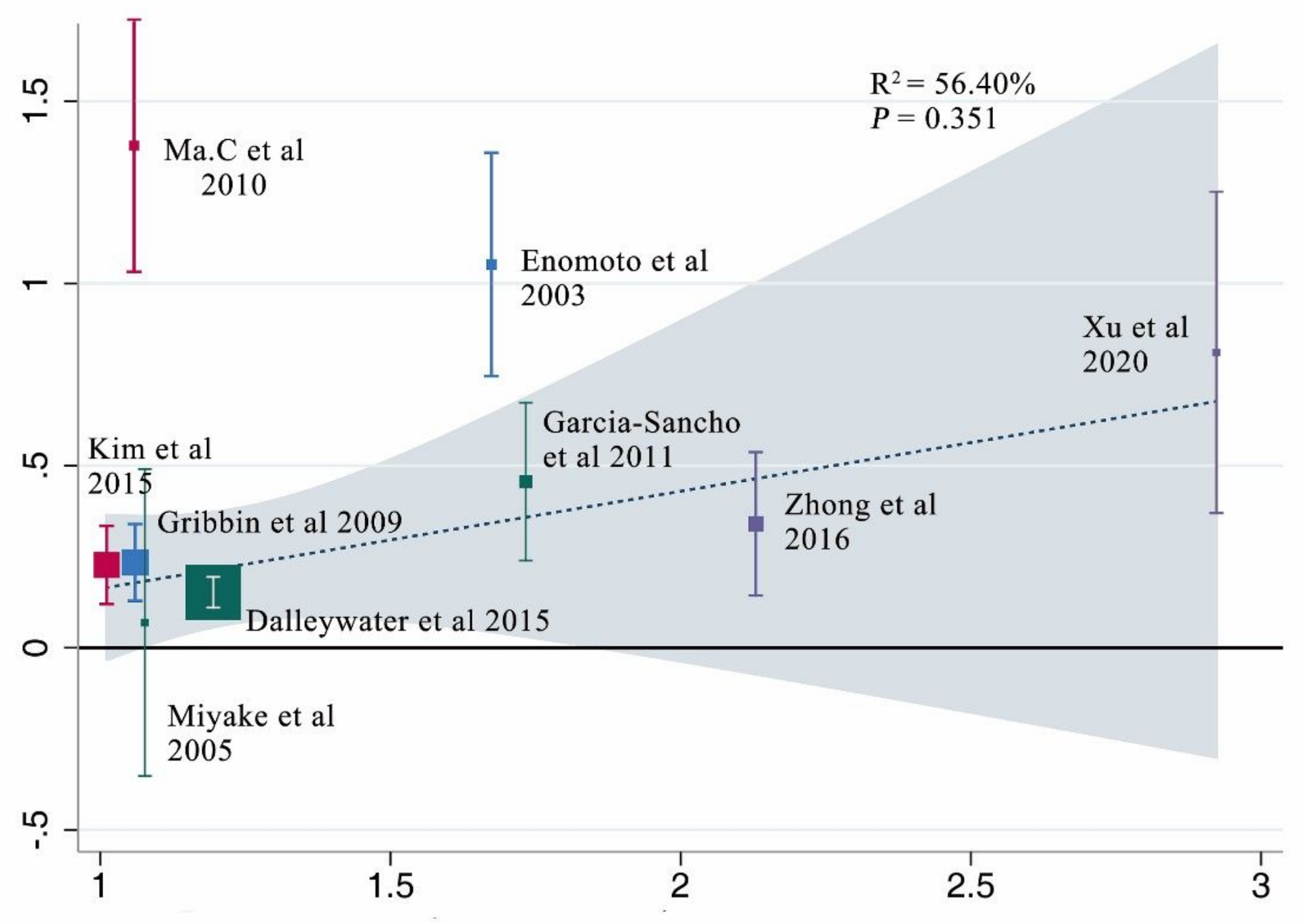

Figure 5

Meta-regression analysis presenting the impact of smoking on relevance between DM and IPF. The horizontal coordinate represents the ratio of proportion of smokers (current or past) in IPF group to that in control group in each study while the vertical coordinate accordingly represents the ratios of the morbidity of DM in IPF group to that in control group. No significant linear correlation was found $(P=0.351>0.05)$ and the result indicated that smoking didn't affect the association between DM and IPF. 


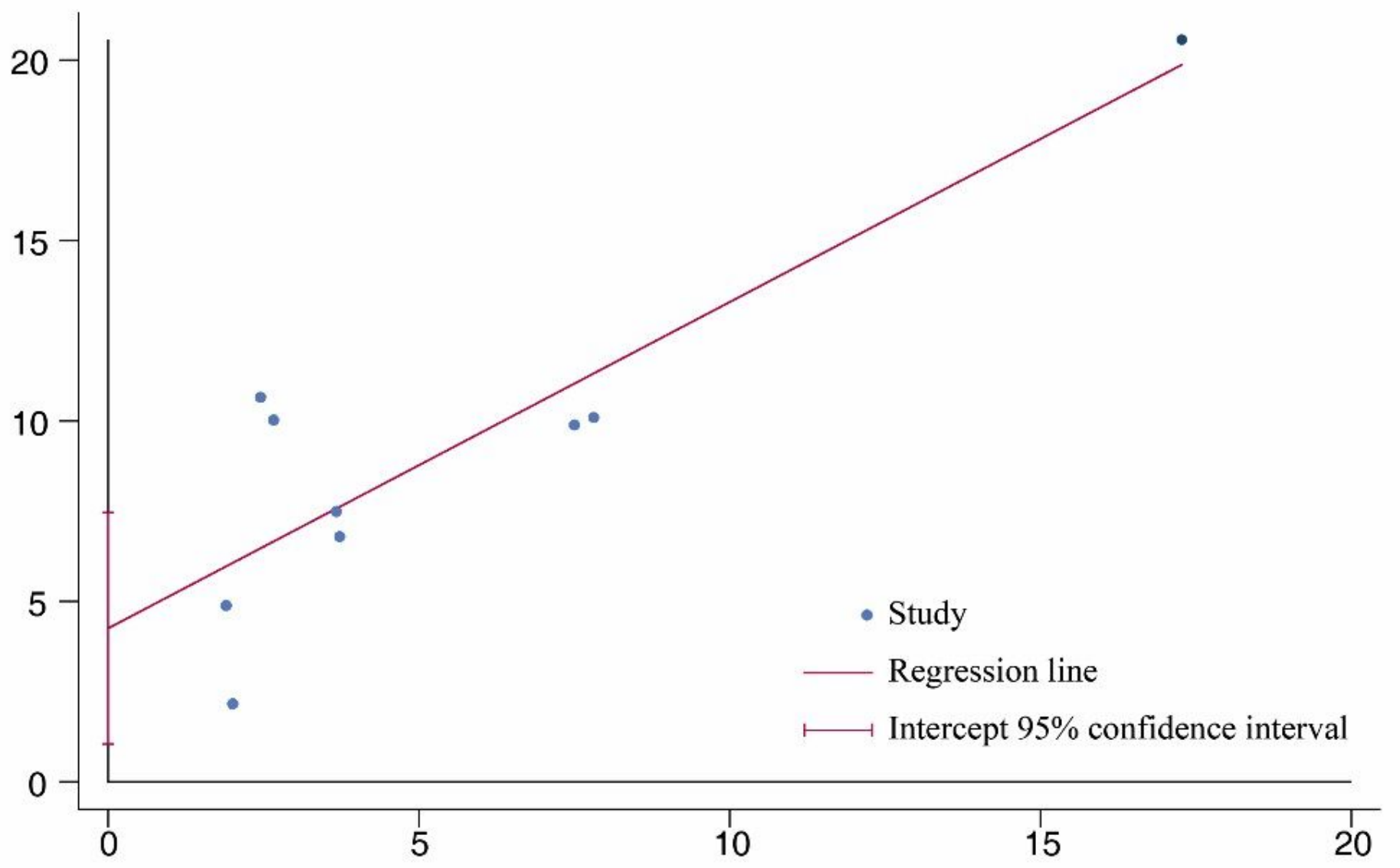

Figure 6

Egger's publication bias plot for included studies

\section{Supplementary Files}

This is a list of supplementary files associated with this preprint. Click to download.

- Appendix1CompleteSearchStrategy.docx 